\title{
PENGGEMUKAN KEPITING BAKAU (SCYLLA SERRATA) DENGAN PAKAN YANG BERBEDA
}

\author{
Giant Mangrove Crab (Scylla serrata) Fattening With Different Feeds \\ Amizar Adila ${ }^{*}$, Septifitri $^{2}$, Muhammad Ali $^{3}$ \\ ${ }^{1}$ LPMUKP Bangka Belitung \\ ${ }^{2}$ Dinas Kelautan dan Perikanan Provinsi Sumatera Selatan \\ ${ }^{3}$ Balai Riset Perikanan Perairan Umum dan Penyuluhan Perikanan Palembang \\ *Corresponding author : amizaradila16@gmail.com
}

\begin{abstract}
ABSTRAK
Kepiting bakau (Scylla serrata) merupakan jenis yang dominan di Indonesia, penggemukkan Kepiting Bakau, masih perlu dikembangkan karena Kepiting Bakau dari hasil tangkapan nelayan tubuhnya keropos. Ketersediaan Kepiting Bakau masih tergantung pada musiman. Penelitian ini bertujuan untuk mengetahui pengaruh pemberian jumlah pakan yang berbeda terhadap pertumbuhan dan kelangsungan hidup Kepiting Bakau, mengetahui konversi pakan (FCR) selama penggemukkan Kepiting Bakau, dan mengetahui jumlah pakan yang paling baik secara ekonomis untuk penggemukkan Kepiting Bakau. Penelitian ini menggunakan Rancangan Acak Lengkap (RAL) dengan 3 (tiga) taraf perlakuan, masingmasing perlakuan dilakukan 3 (tiga) kali ulangan, yaitu Persentase Jumlah Pakan Ikan Rucah Per Karamba $5 \%$, 10\%, dan 15\% dari berat tubuh kepiting. Hasil penelitian menunjukkan bahwa Pemberian pakan ikan rucah 15\% selama 15 hari pada P3 pertambahan berat Kepiting Bakau sangat baik dengan rata-rata sebesar 77.37 gram dengan SR 92\%, konversi pakan (FCR) selama Penggemukkan Kepiting Bakau yang baik adalah di perlakuan P3 sebesar 7.39.
\end{abstract}

Kata kunci : Kepiting Bakau (Scylla serrata), Penggemukkan, dan Ikan Rucah

\begin{abstract}
Giant Mangrove crab (Scylla serrata) is the dominant species in Indonesia, mangrove crab fattening, still needs to be developed because mangrove crab from fishermen's catches is porous. The availability of mud crabs still depends on the seasonality. This study aims to determine the effect of giving different amounts of feed on growth and survival of mud crabs, determine feed conversion (FCR) during mud crab fattening, and determine the best amount of feed economically for mangrove crab fattening. This study used a completely randomized design (CRD) with 3 (three) levels of treatment, each treatment was carried out 3 (three) replications, namely the percentage of trash fish feed per cage 5\%, 10\%, and $15 \%$ of the body weight of the crabs.. The results showed that the feeding of trash fish 15\% for 15 days at P3 weight gain of mangrove crabs was very good with an average of 77.37 grams with SR 92\%, feed conversion (FCR) during the fattening of mangrove crabs was good in P3 treatment of 7.39 .
\end{abstract}

Keywords: Mud Crab (Scylla serrata), Fattening and Trash Fish 


\section{PENDAHULUAN}

Kepiting bakau (Scylla serrata) merupakan jenis yang dominan di Indonesia. Menurut Prianto (2007) Kepiting Bakau (Scylla serrata) merupakan salah satu jenis komoditas laut yang potensial untuk dibudidayakan karena mempunyai nilai ekonomis tinggi, serta mendatangkan keuntungan bagi masyarakat di daerah tempat populasi Kepiting Bakau hidup. Kehidupan Kepiting Bakau di alam tubuhnya banyak kurang berisi atau keropos. Persaingan mendapatkan makanan, menjadikan Kepiting Bakau bisa saling memangsa sesamanya (kanibalisme) (Nurdin dan Armando, 2010).

Upaya penggemukkan Kepiting Bakau, masih perlu dikembangkan karena Kepiting Bakau dari hasil tangkapan nelayan, tubuhnya kurang berisi, berat menjadi turun kurang diminati konsumen, sehingga nilai ekonomis menurun. Salah satu cara yang dapat ditempuh untuk mengurangi terjadinya kepiting yang kurang berisi/keropos dan pemangsaan (kanibalisme) melalui penyediaan tempat berlindung adalah pemilihan dan pemenuhan kebutuhan pakan yang cukup dan tepat. Makanan yang biasa dimakan kepiting biasanya sudah mengalami pembusukkan dan proteinnya sudah menurun. (Wedjatmiko \& Dharmadi. 1994) meneliti bahwa pakan ikan Rucah segar dapat mempercepat pertumbuhan kepiting. Ikan Rucah segar mampu mendorong pertumbuhan kepiting bakau dalam waktu yang singkat, penggunaan ikan-ikan rucah (trash fish atau fish bycatch) yang masih segar dan beku lainnya yang belum mengalami proses pembusukkan untuk makanan kepiting sangat baik pada budidaya Kepiting Bakau dan diharapkan pakan ikan ikan-rucah memberikan hasil sesuai yang diharapkan yang akan tejadi respon cepat terhadap penggemukkan Kepiting Bakau (Scylla serrata) (Mardjono dkk, 1992).

\section{MATERI DAN METODE}

Penelitian ini telah dilaksanakan selama 15 hari, dimulai pada bulan Oktober hingga bulan November, Penelitian ini berlokasi di Desa Tuik, Kecamatan Kelapa, Kabupaten Bangka Barat provinsi Bangka Belitung

Bahan yang digunakan dalam penelitian ini adalah Kepiting Bakau (Scylla serrata), pakan Ikan Rucah dan air,

Alat yang digunakan kawat ayam, baskom, meteran, penggaris, bambu, kawat pengikat, tali, kayu, termometer, $\mathrm{pH}$ meter, timbangan.

Penelitian ini menggunakan Rancangan Acak Lengkap (RAL) dengan 3taraf perlakuan dan 3 ulangan, yaitu :

$$
\begin{aligned}
& \text { P1 = Persentase Jumlah Pakan } \\
& \text { Ikan Rucah Per Karamba } 5 \% \\
& \text { dari berat tubuh kepiting } \\
& \text { P2 = Persentase Jumlah Pakan } \\
& \text { Ikan Rucah Per Karamba } 10 \\
& \% \text { dari berat tubuh kepiting } \\
& \text { P3 = Persentase Jumlah Pakan } \\
& \text { Ikan Rucah Per Karamba } 15 \\
& \% \text { dari berat tubuh kepiting }
\end{aligned}
$$

\section{Prosedur Penelitian}

\section{Persiapan Media dan Wadah}

\section{Pemeliharaan}

Media air pemeliharaan menggunakan dari air sungai itu sendiri, persiapan wadah meliputi tempat pemeliharaan (Karamba) dengan ukuran $1 \mathrm{~m} \times 1 \mathrm{~m} \times 1 \mathrm{~m}$ dan ketinggian media air 30 $\mathrm{cm}$. Pengaturan tata letak Karamba yang digunakan dalam penelitian dengan sistem memanjang mengikuti aliran sungai, Karamba digukanan 9 buah dengan kepadatan 9 ekor Kepiting Bakau keropos atau kurus. 


\section{Persiapan Kepiting Uji}

Kepiting Bakau (Scylla serrata) yang tidak berisi/keropos digunakan dalam penelitian berukuran berat 200 gram/ekor dan umur 12 bulan. Kepiting Bakau terlebih dahulu diseleksi berdasarkan kepiting bakau yang keropos atau kurus, kemudian ditimbang untuk keseragaman ukuran bobot tubuh kepiting.

\section{Seleksi Kepiting Bakau}

Seleksi dilakukan dipengepul terlebih dahulu, agar kepiting untuk penggemukkan bisa berukuran seragam. Lalu dilakukan pengangkutan ke lokasi budidaya Kepiting Bakau untuk dipelihara sampai gemuk. Tahap seleksi Kepiting Bakau dipilih sesuai syarat Kepiting yang baik tidak cacat, semua anggota tubuh lengkap dan warna cerah tidak ada bercak- bercak hitam yang menandakan jamur. Adanya reaksi yang cepat jika kaki jalan atau kaki renangnya ditarik dan mata yang aktif bergerak jika diganggu.

Membedakan jenis kelamin dari Kepiting Bakau jantan dan betina dapat dilakukan dengan mengamati bentuk luar tubuhnya. Hal ini dituturkan oleh Tiurlan et al. (2019) yang menyebutkan bahwa organ kelamin kepiting jantan berbentuk segitiga agak runcing yang menempel di bagian perutnya, sedangkan organ kelamin kepiting betina berbentuk segitiga yang relatif lebar dan bagian depannya agak tumpul. Cara lain membedakan jenis kelamin kepiting adalah dengan memperhatikan ruas-ruas abdomennya. Ruas abdomen kepiting jantan jauh lebih sempit dibandingkan dengan ruas abdomen Kepiting betina.

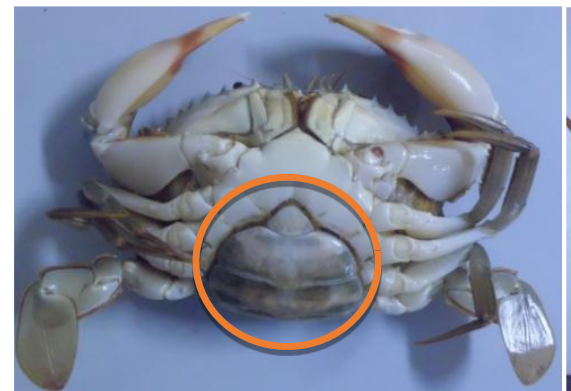

S. serrata betina

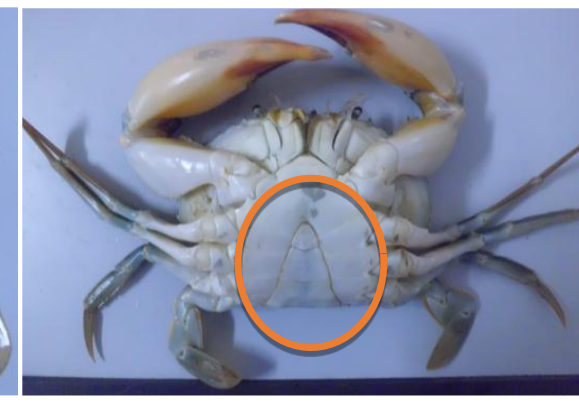

S. serrata jantan

Gambar 1. Jenis Kelamin jantan $(\precsim)$ dan betina () Kepiting Bakau

\section{Penebaran Kepiting}

Sebelum ditebarkan kedalam karamba, kepiting diaklimatisasi terlebih dahulu dan sebaiknya penebaran kepiting dilakukan pada pagi hari dan sore hari. untuk mengindari terjadinya stress, kepadatan kepiting dalam karamba adalah 9 ekor $/ m^{2}$ yang berukuran berat 200 gram

\section{Pengamatan Kualitas Air}

Nilai parameter kualitas air yang diamati selama penggemukkan Kepiting Bakau meliputi : ph, suhu DO dan salinitas yang dimaksudkan untuk mendapatkan gambaran tentang kondisi lingkungan tempat hidup kepiting.

\section{Parameter yang Diamati}

Kelangsungan Hidup (SR)

Tingkat kelangsungan hidup dihitung selama pemeliharaan menggunakkan rumus Effendi (1997). Parameter yang diamati adalah sebagai berikut :

$$
S R=\frac{N t}{N_{0}} \times 100 \%
$$

Keterangan :

$\mathrm{SR}=$ Kelangsungan hidup $(\%)$

$\mathrm{Nt}=$ Jumlah ikan akhir pemeliharaan (ekor)

No=Jumlah ikan pada awal penebaran (ekor) 


\section{Perhitungan Berat}

Perhitungan data penambahan ukuran seperti berat, dilakukan dengan mengacu pada rumus Zonneveld (1991).

Berat $=\frac{(\text { berat akhir }- \text { berat awal })}{\text { berat awal }} \times 100 \%$

\section{Food Convertion Ratio (FCR)}

Perhitungan FCR mengacu pada rumus Tacon (1987) sebagai berikut :

$\mathrm{FCR}=\frac{\mathrm{F}}{\mathrm{Wt}-\mathrm{Wo}}$

Keterangan :

$\mathrm{FCR}=$ Food Conversation Ratio/ Rasio Konversi Pakan
$\mathrm{F} \quad=$ Jumlah pakan yang dikonsumsi (g)

$\mathrm{Wt}=$ Berat hewan uji pada akhir penelitian (g)

Wo $=$ Berat hewan uji pada awal penelitian (g)

\section{HASIL DAN PEMBAHASAN}

\section{Pertumbuhan Berat}

Pertumbuhan berat rata-rata Kepiting Bakau yang tertinggi setelah dipelihar selama 15 hari adalah pada perlakuan P3 sebesar 277.3611 gram diikuti dengan Perlakuan P2 sebesar 225.1389 gram dan pertumbuhan berat rata-rata kepiting bakau terkecil pada Perlakuan P1 sebesar 216.5476 gram.

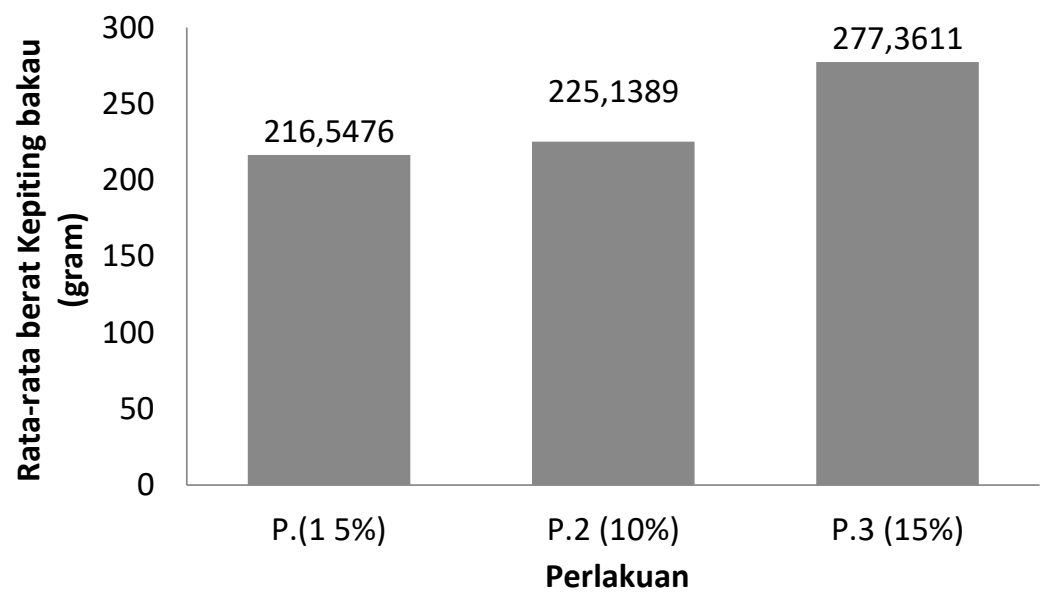

Gambar 2. Nilai rata-rata Pertumbuhan berat Kepiting Bakau selama 15 hari

Berdasarkan data hasil penelitian diketahui bahwa terdapat pertambahan berat yang terbaik ada Kepiting Bakau yang diberi pakan ikan rucah P3 (15\%) dibandingkan dengan pemberian pakan ikan rucah P1 (5\%) dan P2 (10\%). Perlakuan P1 menunjukkan pertambahan berat terendah dibandingkan dengan perlakuan lainnya ( P2 dan P3).

Perlakuan P2 sudah menunjukkan peningkatan pertambahan berat sebesar 25.14 gram karena perlakuan P2 ditambahkan pakan ikan rucah menjadi $10 \%$. Adanya pertambahan berat kepiting bakau terlihat dari peningkatan berat kepiting bakau. Untuk perlakuan P3 peningkatan pertambahan kepiting bakau berat rata-ratanya sebesar 77.36 gram terlihat signifikan karena perlakuan P3 pemberian pakan ikan rucah sebanyajk $15 \%$ dibandingkan $\mathrm{P} 1$ dan $\mathrm{P} 2$.

Pemberian pakan ikan rucah $5 \%$ lebih rendah menurut Suprapto et al. (2014) disebabkan karena jumlah pakan yang diberikan lebih rendah, tidak mencukupi kebutuhan Kepiting Bakau. Sehingga hanya mampu meningkatkan pertambahan berat yang relatif rendah karena pakan ikan 
rucah yang dimakan kepiting bakau tersebut tidak mencukupi semua jumlah kepiting P1. perlakuan P1 menunjukkan pertambahan berat terendah dibandingkan dengan perlakuan lainnya ( P2 dan P3). Pada pemberian pakan ikan Rucah $5 \%$ lebih rendah, disebabkan karena jumlah pakan yang diberikan lebih rendah, tidak mencukupi kebutuhan Kepiting Bakau. Sehingga hanya mampu meningkatkan pertambahan berat yang relatif rendah karena pakan ikan Rucah yang dimakan kepiting bakau tersebut tidak mencukupi semua jumlah kepiting P1.

Tabel 1. Uji Duncan Pertambahan Berat Kepiting Bakau (Scylla serrata) Dengan Pakan Yang Berbeda.

\begin{tabular}{|c|c|c|c|c|}
\hline Perlakuan & $\begin{array}{c}\text { Rata-Rata } \\
\text { Pertambahan Berat }\end{array}$ & $\mathbf{P 1}$ & $\mathbf{P 2}$ & $\mathbf{P 3}$ \\
\hline $\mathrm{P} 1$ & 16.55 & & & \\
\hline $\mathrm{P} 2$ & 25.14 & 8.59 & & \\
\hline \multirow[t]{2}{*}{ P3 } & 77.36 & $60.81 * *$ & $52.22 * *$ & \\
\hline & $\mathrm{D} 0,05=16$ & & D 0 & .040 \\
\hline
\end{tabular}

Dari hasil uji Duncan didapat perlakuan P3 (15\% pemberian pakan ikan Rucah) berbeda sangat nyata dengan perlakuan $\mathrm{P} 1(5 \%$ pemberian pakan ikan Rucah) dan P2 (10\% pemberian pakan ikan Rucah). Berdasarkan data hasil penelitian diketahui bahwa terdapat pertambahan berat yang terbaik pada Kepiting Bakau yang diberi pakan ikan Rucah P3 (15\% pemberian pakan ikan Rucah) dibandingkan dengan pemberian pakan ikan Rucah P1 (5\% pemberian pakan ikan Rucah) dan P2 (10\% pemberian pakan ikan Rucah). Sedangkan hasil perhitungan Kelangsungan Hidup Kepiting Bakau yang dipelihara selama 15 hari dapat dilihat pada gambar 3.

Perlakuan P2 sudah menunjukkan peningkatan pertambahan berat sebesar 25.14 gram karena perlakuan P2 ditambahkan pakan ikan Rucah menjadi $10 \%$. Adanya pertambahan berat Kepiting Bakau terlihat dari peningkatan berat kepiting bakau. Untuk perlakuan P3 peningkatan pertambahan berat rata-rata Kepiting Bakau sebesar 77.36 gram terlihat signifikan karena perlakuan P3 pemberian pakan ikan Rucah sebanyak 15\% dibandingkan P1 dan P2. Hal ini karena pemberian pakan ikan Rucah $15 \%$ lebih cepat terhadap penambahan berat Kepiting Bakau (Scylla serrata) (Mardjono dkk, 1992).

Hal ini disebabkan karena perlakuan P2 dan P3 pakan ikan rucah lebih tinggi dari perlakuan P1. Rusdi dab Zafran (2007) menyatakan bahwa pertumbuhan kepiting yang dipelihara dalam karamba mengalami pertumbuhan yang berbeda sesuai dengan frekuensi pemberian pakannya. Menurut Suprarto et al. (2014) pakan yang dikonsumsi oleh ikan secara umum akan mengalami proses pencernaan, penyerapan, pengangkutan dan metabolisme. Ikan rucah mempunyai kandungan protein 58,97\%, karbohidrat $2,71 \%$, lemak $6,54 \%$ abu, 27,98\% (Utomo et al. 2013). Pertumbuhannya kepiting membutuhkan protein lebih banyak dari pada hewan darat dan kebutuhan protein bagi kepiting tergantung dari jenis, umur, reproduksi, dan lingkungan hidupnya. 


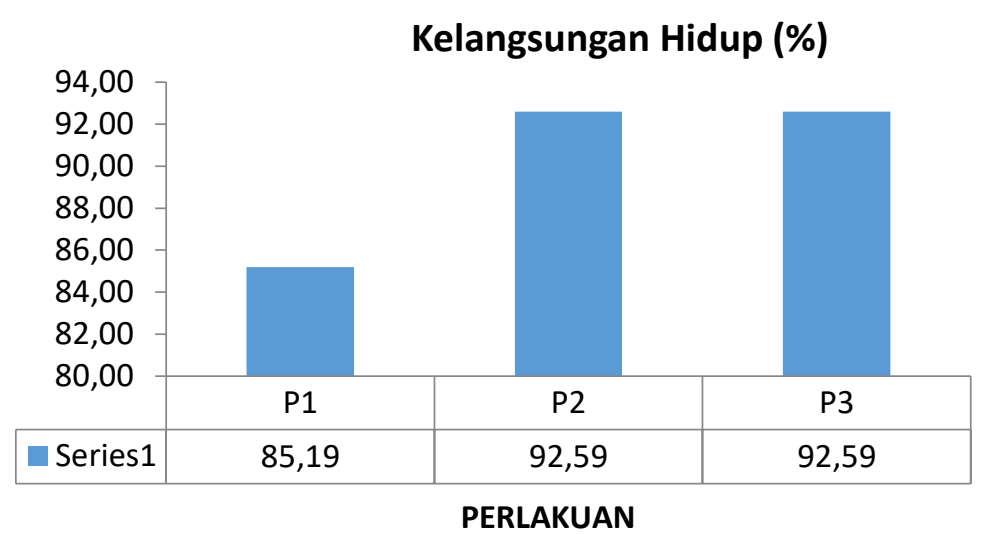

Gambar 3. Nilai rata-rata Kelangsungan Hidup Kepiting Bakau

Perlakuan P1 $(5 \%$ pemberian ikan rucah) menghasilkan kelangsungan hidup terendah dengan rata-rata sebesar $85.19 \%$ dibandingkan dengan perlakuan P2 (10\%) dan P3 (15\%). Selama penelitian berlangsung mortalitas (kematian) Kepiting Bakau (Scylla serrata) banyak terjadi pada akhir penelitian dan awal penelitian. Selama penelitian berlangsung mortalitas (kematian) Kepiting Bakau (Scylla serrata) banyak terjadi pada akhir penelitian dan awal penelitian, ini diduga terjadi karena proses aklimatisasi terlalu singkat dan kanibalisme, sehingga pada saat penelitian kepiting mengalami stress (sering muncul kepermukaan dan menempel pada karamba pada bagian atas). Menurut Bardach et al. (1972) kondisi stress yang muncul dapat menurunkan tingkat efisiensi pakan yang selanjutnya apabila tidak dapat memanfaatkan makanan, maka tidak ada energy untuk bertahan hidup serta tumbuh sehingga peluang menuju kematian semakin besar. Disamping itu mortalitas juga disebabkan karena persaingan ruang gerak dalam perebutan makanan dan lepasnya kaki renang akibat tersangkut kawat karamba sehingga memungkinkan kepiting bakau yang lemah mengalami penurunan nafsu makan dan mengalami kematian.

Perlakuan P2 pemberian pakan $10 \%$ dan P3 pemberian pakan 15\% menghasilkan kelangsungan hidup yang tertinggi selama penelitian. Hal ini disebabkan oleh pada Perlakuan P2 (10\%) dan P3 (15\%) asupan makanan terpenuhi sehingga kegiatan kanibalisme terhadap kepiting lain berkurang dari perlakuan P1 yang hanya pemberian pakan ikan rucah $(5 \%)$.

Perlakuan P2 pemberian pakan 10 $\%$ dan P3 pemberian pakan 10 menghasilkan kelangsunga hidup yang tertinggi selama penelitian. Hal ini disebabkan karena perlakuan P2 dan P3 pakan ikan rucah lebih tinggi dari perlakuan P1. Hasil perhitungan Konversi Pakan Kepiting Bakau yang dipelihara selama 15 hari FCR Kepiting Bakau dapat dilihat pada Gambar 4. 


\section{FCR Pakan}

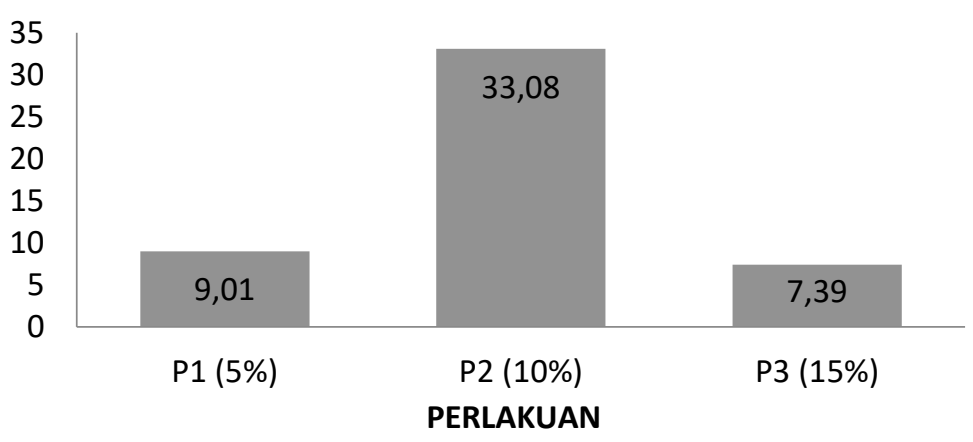

Gambar 4. Rasio Konversi Pakan Kepiting Bakau selama 15 hari

Dari Gambar 4 dapat dilihat bahwa FCR Kepiting Bakau yang tertinggi pada perlakuan P2 sebesar 33.08 diikuti oleh perlakuan P1 sebesar 9.01 dan perlakuan P3 terkecil sebesar 7.39. FCR pada perlakuan P3 (7.39) kecil dari Perlakuan P2 (33.08) dan Perlakuan P1 (9.01). hal ini menunjukkan pada Perlakuan P3, pakan yang diberikan lebih efisien dibandingkan dengan perlakuan P2 dan P1. Menurut Saputra et al. (2018) semakin tinggi nilai rasio konversi pakan (FCR), maka semakin

\begin{abstract}
tidak efisien pemberian pakan. Hasil dimanfaatkan guna menunjang pertumbuhan. Kim dan Lall (2001) menyatakan bahwa, hampir $60 \%$ energi pakan yang dikonsumsi organisme digunakan untuk energi pertumbuhan yang masuk melalui jumlah pakan yang dikonsumsi bersumber dari protein, lemak dan karbohidrat, sebagai sumber energi yang utama. Perbedaan FCR rata-rata Kepiting Bakau selama 15 hari dapat dilihat pada tabel 3.
\end{abstract}

Tabel 2. Hasil Analisis Sidik FCR Ragam Kepiting Bakau (Scylla serrata) Dengan Pakan Yang Berbeda Selama Penelitian.

\begin{tabular}{lcrlllc}
\hline \multicolumn{1}{c}{ SK } & DB & JK & KT & Fhitung & \multicolumn{2}{c}{ Ftabel } \\
\cline { 6 - 7 } & & & & & $\mathbf{5 \%}$ & $\mathbf{1 \%}$ \\
Perlakuan & 2 & 72.657 & 36.3284 & $6.03020252 *$ & 5.14 & 10.92 \\
Galat & 6 & 36.146 & 6.02441 & & & \\
Total & 8 & 108.803 & & & & \\
Keteranga $: *=$ berbeda & nyata $(F$ hitung $>$ Ftabel $5 \%$ & & &
\end{tabular}

\section{Kualitas Air Pemeliharaan}

Tabel 3. Kualitas air selama pemeliharaan

\begin{tabular}{ccccc}
\hline Media Penelitian & \multicolumn{3}{c}{ Parameter } \\
\cline { 2 - 5 } & Suhu $\left({ }^{\circ} \mathbf{C}\right)$ & $\mathbf{p H}$ & Salinitas & DO \\
Air Payau & $26-30$ & $5.5-7.0$ & $16-25$ & $5.7-7.6$ \\
\hline
\end{tabular}

Dari Tabel 3 diatas dapat dilihat bahwa kisaran suhu air selama penelitian antara 26-30 ${ }^{\circ} \mathrm{C}$, sedangkan $\mathrm{pH}$ air antara 5.5-7.0, Salinitas 16-25 dan DO antara 5.7-7.6 ppt.
Kisaran salinitas selama penelitian baik berkisar 16-26 ppt pada saat penebaran salinitas air dalam kondisi air surut berkisar $16 \mathrm{ppt}$, air pasang bersalinitas $26 \mathrm{ppt}$ dalam 
masih keadaan baik untuk budidaya Kepiting Bakau. Kualitas air media pada masing-masing perlakuan dan ulangan selama penelitian masih dalam batas toleransi kehidupan Kepiting Bakau (Scylla serrata) Trino et al. (2001); Christensen et al. (2004) menyatakan bahwa untuk pertumbuhan Kepiting Bakau yang optimal suhu $27-28{ }^{0} \mathrm{C}$ dan $\mathrm{pH}$ 7,8-8,9. Nilai kisaran DO 3, 7- 8,9 ppm dan salinitas berkisar antara 25-30 ppt.

\section{KESIMPULAN}

Keimpulan yang diperoleh dalam penelitian ini yaitu pemberian pakan ikan rucah $15 \%$ pada P3 pertambahan berat Kepiting Bakau sangat baik dengan ratarata sebesar 77.37 gram, sedangkan konversi pakan (FCR) selama Penggemukkan Kepiting Bakau yang baik adalah di perlakuan P3 sebesar 17.67 gram dengan rata-rata sebesar 5.89 gram dan jumlah pakan yang baik di perlakuan P3 (pemberian pakan ikan rucah sebesar 15\%).

\section{DAFTAR PUSTAKA}

Bardach, J.H. Ryther and W.O. Mc Larney.1972. aquaculture. The Farming And Husbany of Fresh Waterand Marine Organisme. Jhon and Sons, New York.

Effendie, M. I. 1997. Metode Biologi Perikanan. Yayasan Pustaka Nusantara, Yogyakarta. 163 hal.

Saputra I, Putra WKA, Yulianto T. 2018. Tingkat konversi dan efesiensi pakan benih ikan bawal bintang (trachinotus blochii) dengan frekuensi pemberian berbeda. Jurnal of Aquaculture Science. 3 (2): 170-181.

Kim, J.D. \& S.P. Lall. 2001. Effect of dietary protein level on growth and utilization of protein and energy by juvenile haddock (Melanogrammus aeglefinus). Aquaculture 195:311319.

Mardjono,M., Anindiastuti, Noor hamid , Iin S.Djunaidah dan W.H.Satyantini. 1994, Pedoman Pembenihan Kepiting Bakau Scylla serrata. BBAP Jepara. 1994.

Nurdin, M. dan Armando, R. 2010. Cara Cepat Panen Kepiting Soka dan Kepiting Telur. Penebar Swadaya. Bogor. Hlm. 48-56.

Prianto, E. 2007. Peran Kepiting Sebagai Spesies Kunci (Keystone Spesies) pada Ekosistem Mangrove. Prosiding Forum Perairan Umum Indonesia IV. Balai Riset Perikanan Perairan Umum. Banyuasin.

Utomo NBP, Susan, Setiawati M. 2013. Peran tepung ikan dari berbagai bahan baku terhadap pertumbuhan lele sangkuriang Clarias sp. Jurnal Akuakultur Indonesia. 12 (2): 158168.

Rosmaniar, 2008. Kepadatan Dan Distribusi Kepiting Bakau (Scylla serrata) Serta Hubungannya Dengan Faktor Fisik Kimia Di Perairan Pantai Labu Kabupaten Deli Serdang [Tesis].

Suprapto D, Widowati I, Yudiati E, Subandiyono. 2014. Pertumbuhan kepiting bakau Scylla serrata yang diberi jenis pakan. Jurnal Ilmu kelautan. 19 (4): 202-210.

Tacon. A. G. J. 1987. Nutrition and Feeding of Farmed Fish and Shrimp, Governent Cooperative Programme (FAO), Brasil. 79-80.

Tiurlan E, Djunaidi A, Supriyantini E. 2019. Aspek reproduksi kepiting 
bakau (Scylla sp.) di peraiaran Kendal, Jawa Tengah. Journal of Tropical Marine Science. 2 (1): 2936.

Trino, A.T., Millamena, O.M., \& Keenan, C.P. 2001. Pond Culture of Mud Crab Scylla serrata (Forskal) Fed Formulated Diet With or Without Vitamin and Mineral Supplements. Proc. Int. Forum on the Culture of Portunid Crabs. Asian Fisheries Society, Manila, Philippines. Asian Fisheries Science, 14: 191-200

Wedjatmiko \& Dharmadi. 1994. Peng.

frekuensi pemberian pakan terhadap pertumbuban kepiting bakau (Scylla serrata). (The effect of feeding frequency on mud crab (Scylla serrata) growth). Warta Balitdita (Coastal Aquaculture Newsletter), 6(3): 37-39.

Zonneveld, C. 1991. Estimating death rates from transect counts. Ecological Entomology. 16(1):115-121. 